17. Зализняк Л.Л. Мезолит Юго-Восточного Полесья. К.: Наукова думка, 1984. 119 с.

18. Залізняк Л.Л. Первісна історія Украіни. К.: Віща школа, 1999. 263 с.

19. Охріменко Г. Волинська неолітична культура. Луцьк: Волинська обласна друкарня, 2001. 154 с.

20. Охрименко Г.В. Волынская неолитическая культура: хронология и периодизация // Проблемы хронологии и этнокультурных взаимодействий в неолите Евразии (хронология неолита, особенности культур и неолитизация регионов, взаимодействие неолитических культур в Восточной и Средней Европе). СПб.: ИИМК РАН, 2004. С. 131-137.

21. Калечыц А.Г. Што паказалі археалагічныя досьледы на Заходнім Палессі (па матэрыялах Мотальскага мікрарэгіёна) // Badania archeologiczne w Polsce północno-wschodniej i na zachodniej Białorusi w latach 2000-2001. Materiały z konferencji, Białystok 6-7 grudnia 2001 roku. Białystok, 2002. S. 123-133.

22. Ткачоў А. Кераміка ляснога неаліту з тэрыторыі Беларускага Пабужжа // Супольнасці каменнага i бронзавага вякоў міжрэчча Віслы і Дняпра: Зборнік навуковых артыкулаў памяці Міхала Чарняўскага. Мн.: А.М. Янушкевіч, 2015. C. 143-164.

23. Józwiak B., Domaradzka S. Studia nad osadnictwem społeczności subneolitycznych w Polsce pólnocno-wschodniej. Zarys prodlematyki // $\mathrm{Na}$ rubieży kultur. Badania nad okresem neolitu i wczesną epoką brązu. Białystok: Muzeum Podlaskie, 2011. S. 87-101.

24. Wawrusiewisz A. Okres neolitu i wczesnej epoki brązu na Podlasiu. Stan i perspektywy badań // Na rubiezy kultur. Badania nad okresem neolitu i wczesną epoką brązu. Białystok: Muzeum Podlaskie, 2011. S. 13-36.

25. Wawrusiewisz A. Ceramika typu Sokołówek na Podlasiu i jej znaczenie w rozwoju spoleczności subneolitycznych Polski Północno-Wschodniej // Studia i materialy do badań nad neolitem i wczesną epoką brązu na Mazowszu i Podlasiu. T. III, Warszawa, 2013. S. 5-24.

26. Wawrusiewisz A. Ceramika wczesnosubneolityczna na Podlasiu. Przyczynek do badań nad genezą kultury niemeńskiej // Супольнасці каменнага і бронзавага вякоў міжрэчча Віслы і Дняпра: Зборнік навуковых артыкулаў памяці Міхала Чарняўскага. Мн.: А.М. Янушкевіч, 2015. С. 123-142.

27. Kempisty E. Kultura ceramiki «grzebykowo-dołkowej» na Mazowszu i Podlasiu // Wiadomości archeologiczne, t. XXXVIII/1, 1973. S. 3-76.

28. Józwiak B. Społeczności subneolitu wschodnioeuropejskiego na Niżu Polskim w międzyrzeczu Odry I Wisly, Materiały do syntezy pradziejów Kujaw, nr. 11, Poznań, 2003.

29. Чарняўскі М.М. Нёманская неалітычная культура ў Беларусі: генезіс і эвалюцыя // Na rubieży kultur. Badania nad okresem neolitu i wczesną epoką brązu. Białystok: Muzeum Podlaskie, 2011, S. 77-86.

\title{
EARLY NEOLITHIC POTTERY OF WESTERN BELARUS: CURRENT STATE OF RESEARCH AND ITS PERSPECTIVES
}

(C) 2017

Tkachou Aleh Yurjevich, researcher of Archaeology of Prehistoric Society Department Institute of History of National Academy of Sciences of Belarus (Minsk, Republic of Belarus)

Abstract. The paper discusses the Early Neolithic pottery from the Western Belarus, pottery of Dubičiai type. The set of its most distinctive features includes organic temper in clay mass, a belt of deep round pits under a rim edge, strokes by round stick («hoofs»), slantwise thin grooved lines or slantwise net ornament of such lines. Hypotheses on the origin of Dubičiai type pottery are under discussion as well. According to many scholars, the area of occurrence of Dubičiai type pottery includes Belarusian part of the River Neman region (except the River Viliya basin), the leftbank of the upper Prypiat River basin, the southern Lithuania, the part of the north-eastern Poland, and the northern part of Volhynia. At the same time D.Ya. Telegin, E.N. Titova, G.V. Okhrimenko distinguish the Volhynian culture in the region of the same name. It has many traits analogous to the Prypiat-Neman culture. The scale of differences between the Early Neolithic pottery from Western Polesia and Volhynia and Dubičiai type pottery from the River Neman region allows considering the Volhynian culture as not a separate culture but as a local variant of the Neman culture. Sokołówek type pottery has been discovered at the sites in Podlasie and in Belarusian part of the River Bug region. It is analogous to Dubičiai type pottery by morphology and ornamentation but has less of organic temper in clay mass. Most probably, it is a result of local development of the Early Neolithic traditions in the western part of Prypiat-Neman culture area.

Keywords: Prypiat-Neman culture; Neman culture; Volhynian culture; Dubičiai type; Sokołówek type; Lysaja Hara type; Dobry Bor type; Western Belarus; River Neman; River Prypiat; River Bug; Prypiat Polesia; River Bug region; Podlasie; Early Neolithic; «forest Neolithic»; Neolithisation; comb-stroke pottery.

УДК 902

Статья поступила в редакцию 22.08.2017

\section{THE SECOND STAGE OF NEOLITHISATION AND PARA-NEOLITHIC IN THE SOUTHERN BALTIC} (C) 2017

Nowak Marek, doctor of humanistic sciences (liberal arts), associate professor of Institute of Archaeology Jagiellonian University (Krakow, Republic of Poland)

Abstract. The origins of the Neolithic, understood as a phenomenon with food economy dependent on agriculture, in east-central Europe are associated with the appearance of communities reflected by the Linear Band Pottery culture (LBK) in ca. 5500 BC. These communities settled only small enclaves, distinguished by ecological conditions favourable to farming. Situation of this kind persisted in the $5^{\text {th }}$ millennium BC, when territories under discussion were inhabited by post-Linear groups. Consequently, at that time, hunter-gatherers still occupied ca. $70 \%$ of these 
territories. Such situation changed from 4200/4100 BC onwards, due to the formation and spectacular territorial «expansion» of the Funnel Beaker culture (TRB). This expansion covered both the areas previously inhabited by huntergatherers and farmers. Around 3500 BC Neolithic formation encompassed virtually the whole of this part of Central Europe. Parallel to the first and second Neolithisations, independent processes of «ceramisation» of the Late Mesolithic communities proceeded. While in the $5^{\text {th }}$ millennium $\mathrm{BC}$ they were fairly selective, in the $4^{\text {th }}$ millennium $\mathrm{BC}$ they were quite intensive. A new cultural model formed here which might be called «para-Neolithic». Archaeological data indicate contacts between TRB and para-Neolithic communities. The latter phenomena (mainly the Neman culture) show also a significant territorial development.

Keywords: southern Baltic; Neolithic; para-Neolithic; Funnel Beaker culture; Neolithisation; ceramisation; Linear Band Pottery culture; agriculture; chronology; hunters and fishermen; Mesolithic; Ertebølle culture; forest Neolithic.

\section{Introduction}

In this paper, several problems related to the Neolithisation of the southern Baltic area, which term roughly corresponds to present-day Poland, will be presented as well as proposals for solving these problems. Particularly, those processes that were not related to the first Neolithic will be its topic.

The origins of the Neolithic, as in other parts of central Europe, are associated with the appearance of the Linear Band Pottery culture (henceforth LBK, after German term Linearbandkeramik), in the mid- $6^{\text {th }}$ millennium BC. These origins were associated with migrations from the middle Danube basin, what is strongly suggested by the genetic data which demonstrate basic differences between the LBK and Mesolithic genetic pools [1-4]. We should emphasize that the LBK, even in its initial and early stages, contains all elements of the so-called Neolithic package. On the other hand, it should also be emphasized that communities of that culture settled only small enclaves, distinguished by ecological conditions favourable to farming (fig. 1).

Situation of this kind persisted in the 5th millennium BC. Different Neolithic groups of the post-Linear character (Stroke Band Pottery culture and Lengyel-Polgár complex) still concentrated within the same enclaves (fig. 1). Undoubtedly, some areas outside these enclaves were penetrated and even exploited by Neolithic groups. That is why we have some Linear and post-Linear findings there. Among such sites there are several ones, like Równina Dolna (north-eastern Poland - [5; 6]), DębyKaczynos (eastern Pomerania - [7]), Osłonino (eastern Pomerania - [8, p. 1950, 1960-1961]), situated, surprisingly, in the very northern regions. However, this does not undermine the fact, that until the end of the 5th millennium $\mathrm{BC}$, at least ca. $70 \%$ of the territory under discussion remained beyond the extent of the compact Neolithic settlement (figs. 1, 2).

Hunter-gatherer communities in ca. 5500-4000 BC

So, the first problem occurs, what was going on outside enclaves settled by aforementioned Early Neolithic groups? This problem concerns actually areas beyond the Baltic coastal zone, because at present nobody doubts that hunter-gatherer groups lived in that zone until ca. $4000 \mathrm{BC}$, as evidenced by ${ }^{14} \mathrm{C}$ datings in Dąbki [9] and Tanowo [10, p. 49-52] (fig. 1).

It would seem logical that hunter-gatherer communities should continue to exist in these inland zones as well. However, in fact this is not so obvious, since connections between radiocarbon dates, later than mid- $6^{\text {th }}$ millennium $\mathrm{BC}$, including also those of the $4^{\text {th }}$ and $3^{\text {rd }}$ millennia $\mathrm{BC}$, obtained in non-Neolithic contexts, comprising the Late Mesolithic flint inventories and - in some cases - pottery, which can be generally referred to as «non-Neolitic»/para-Neolithic (mostly it is pottery of the Neman culture), are contested. The main reason of that is suggested lack of homogeneity of sand and peat sites $[11 ; 12]$.

However, it is possible to put forward some arguments for long chronology of hunter-gatherers in the territory under consideration. Let us highlight three of them [see 13, p. 242-246].

Firstly, the number of radiocarbon dates is fairly high. We have over seventy such dates [13, fig. 40, further literature there], most of them from contexts containing pottery, and some of them from the relatively stratified contexts, like at Chwalim (south-western Greater Poland) $[14 ; 15]$ or Grądy Woniecko (north-eastern Poland) (kind information by A. Wawrusiewicz). The general sum of their probability distributions suggests chronology until the end of the $3^{\text {rd }}$ millennium BC [13, fig. 40].

Secondly, as 40 years ago S.K. Kozłowski observed [16, p. 248], it is impossible to assume a preposterous situation in which non-Neolithic ceramics would not be accompanied by any flint inventory. At least a part of such inventories, which we are not necessarily able to distinguish, has to be connected with the pottery of e.g. Neman culture. Hence, these flint inventories have to be dated to the late $5^{\text {th }}$ millennium $\mathrm{BC}$ and majority of them most probably to $4^{\text {th }}$ and $3^{\text {rd }}$ millennia $\mathrm{BC}$, like the aforementioned pottery.

Thirdly, it is difficult to point out any real reasons for the disappearance of hunter-gatherer groups outside the traditional «Linear» and "post-Linear» enclaves between 5500 and $4000 \mathrm{BC}$. If so, we would have to assume that these vast territories were basically deserted, and this is a rather risky hypothesis.

Therefore, it seems more probable that in the second half of the $6^{\text {th }}$ millennium $\mathrm{BC}$ and in the $5^{\text {th }}$ millennium $\mathrm{BC}$, practically in all southern Baltic territories forager groups lived, parallel to Neolithic groups (fig. 2). These groups belonged to the local Late Mesolithic flint traditions (i.e. Chojnice-Pieńki and late Komornica in western Poland and Janisławice in central and eastern Poland).

Some of these groups underwent «ceramisation», which was independent of the Neolithic. Let us mention here pottery from Tanowo [10, p. 39-48], which is more similar to the Ertebølle pottery, and pottery from Dąbki [17], which has more specific characteristics but also resembles the Ertebølle. The beginnings of this pottery can be dated, based on recent publications, at around 4800/4700 BC. In the Masurian Lake District we also have early-Zedmar ceramics, from about $4300 \mathrm{BC}$ [18], and probably single vessels of the early-Neman (Dubičai) type in the north-eastern Poland (Woźna Wieś?) that can be situated somewhere within the second half of the $5^{\text {th }}$ millennium BC [19].

It seems that contacts between hunter-gatherers and farmers in the $6^{\text {th }}$ and $5^{\text {th }}$ millennia BC were rare [e.g. 20; $10 ; 21]$. Certainly they did not cause major changes in the cultural systems of both formations. 

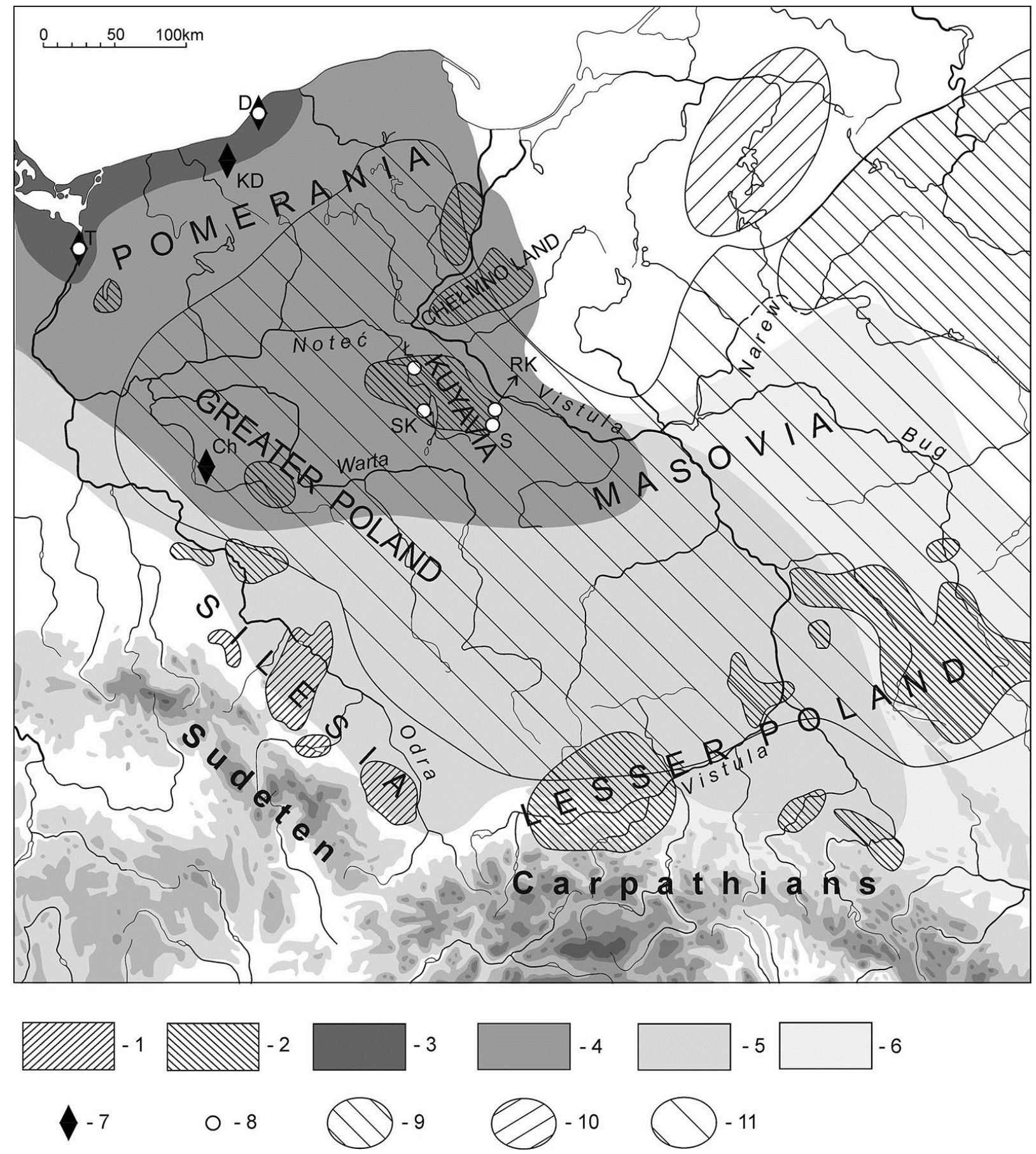

Figure 1 - Southern Baltic area during the Neolithic with phenomena analysed in the article.

1, 2- enclaves settled by communities of the Linear Band Pottery culture (LBK) and post-Linear units, from the mid- $6^{\text {th }}$ to early $4^{\text {th }}$ millennia BC (actual signature marks reflect the situation in the late period of the post-Linear units; 1 - «Lengyel» complex sensu largo (Jordanów culture), 2- «Polgár» complex); 3 - the area of formation of the Funnel Beaker culture (TRB), ca. 4200-4000 BC; 3, 4- range of the TRB C. 4000-3900 BC;

3, 4, 5- range of the TRB, C. 3800/3700 BC; 3, 4, 5, 6- range of the TRB after 3700/3600 BC;

7 - sites with the Ertebølle and Ertebølle-like pottery ( $T$ - Tanowo 3, $D$-Dąbki 9, $K D$-Koszalin-Dzierżęcino,

$C h$-Chobienice); 8 - selected sites with the early TRB pottery ( $T$-Tanowo $3, D$ - Dąbki $9, k$ - Łącko 6 ,

$S K$ - Strzelce Krzyżanna 56, $R K$ - Redecz Krukowy, S - Sarnowo 1); 9 - range of the Neman culture in the late $5^{\text {th }}$ millennium BC; 10 - range of the Zedmar culture; 9, 11-range of the Neman culture in the $4^{\text {th }}$ and $3^{\text {rd }}$ millennia BC

The Funnel Beaker culture

Complex cultural transformations in the Vistula and Oder basins took place between $c a .4200$ and $3500 \mathrm{BC}$. They were associated with the spread of a new model of Neolithic culture within most of the territories of this part of Europe and not only above-mentioned fertile enclaves. Despite singular pieces of evidence confirming the Neolithic use of other environmental zones than above-mentioned fertile enclaves before $c a .4200 \mathrm{BC}$, this ecological, and probably also mental, barrier was apparently not broken by the Linear and post-Linear groups. This was achieved by the societies, whose archaeological legacy is known as the Funnel Beaker culture (henceforth TRB, after German term Trichterbecherkultur). In case of Poland we have to do mainly with its eastern and south-eastern group [e.g. 22]. The spread of the TRB in the basins of the Vistula and Oder rivers can be called the «Second Stage of Neolithisation» [13]. As 
the final result of this process, Neolithic formation filled, in a relatively compact and uniform way, majority of the southern Baltic areas around mid- $4^{\text {th }}$ millennium BC [e.g. 23]. It should be emphasized that this phenomenon refers also to the traditional enclaves of the Early Neolithic settlement, even in the upland zone [e.g. 24] (fig. 2). We should add that with some exceptions agriculture was essential element of food economy of TRB people.

The basic problem associated with the described process is the genesis of TRB and mechanism of its spread. It is our second key problem. As regards the territory under consideration, it should be emphasized that two very early dates obtained at Kuyavian sites Sarnowo and Łącko (see fig. 1), which point to approximately $4500 / 4400$ BC are currently not treated as reliable [25; 13, p. 263-269]. Early pottery dates from Brandenburg (Friesack, Rhinow) and Chelmno Land, of the 4400$4200 \mathrm{BC}$ [26; 27; 25], remain also controversial.

That means that the chronological antecedence should be given to the zone of south-western Baltic coast, because radiocarbon dates obtained recently at several sites in northern Germany and Poland (Wangels, Parow, Stralsund, Baabe, Tanowo and Dąki) point to the period $c a .4200-3950 \mathrm{BC}[28 ; 10$, p. 49-65; 9; 26]. On several sites located there remains of the early TRB were identified, which seem to appear in the context of local hunter-gatherers. To the east of the lower Oder river these groups, from the point of view of flint knapping, can be identified as belonging to the evolved ChojnicePieńki tradition (so-called Tanowo-Bóbr assemblages), while to the west of the said river they belong to the Ertebølle tradition. Therefore, the «Funnel Beaker» early phases are logical continuation of the local, late phases of development of hunter-gatherer culture. Pottery containing features of both the Ertebølle or rather its local derivative and the TRB, like so-called transitional vessels in Dąbki (fig. 3: 3), and perhaps some forms in Tanowo, are significant in this context (fig. 3: 1,2).

Consequently, we assume that the zone extending along the south-western coast of the Baltic Sea, from eastern Holstein to central, perhaps even eastern Pomerania, was the area in which the new cultural model was formed (fig. 1: signature 3). From this zone the spread of this model took place. One can notice in the recent literature that such a construction would be referred primarily to the Northern TRB group [28]. However, we will take the liberty of hypothesizing that this area was the centre of the most original crystallization of Funnel Beaker patterns on the scale of the whole TRB, including also TRB in the Vistula and Odra river basins. First of all, it is hard to imagine that a characteristic Funnel Beaker ceramic stylistics would be invented independently in several centres; there had to be only one such place. Secondly, it is also difficult to imagine that such sites like Dąbki or Tanowo, situated on the south-eastern periphery of the Northern group, played a decisive role in the genesis of this group, but absolutely none in similar processes in the nearer territories of the lower Odra and lower Vistula rivers. We should note that some ceramic forms, described as imports of the earliest pottery of the Eastern TRB group, were discerned in Dąbki [28, p. 215]. Why could not we reverse the postulated relations and consider these forms as the precursors of the pottery set of the TRB Eastern group?
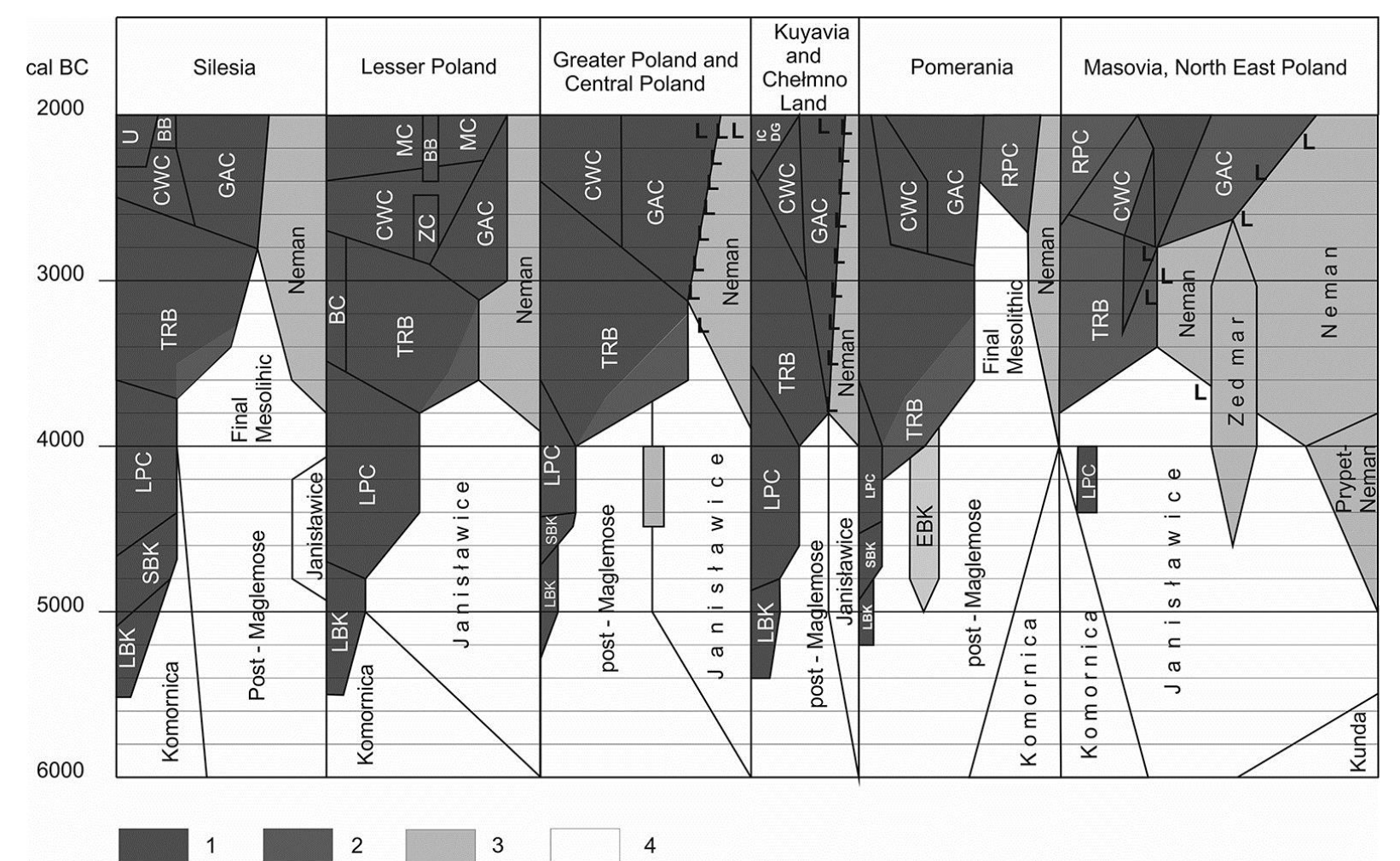

4

Figure 2 - Archaeological cultures and main socio-economic formations in Polish territories between 6000 and 2000 BC (based on: [40, fig. 7] and [13, fig. 114] with significant modifications).

1 - agro-pastoral and pastoral Neolithic; 2-agro-pastoral Neolithic with some contribution of hunting and gathering; 3- pottery-using hunter-gatherers (para-Neolithic); 4- hunter-gatherers (Mesolithic); $L B K$ - Linear Band

Pottery culture; $S B K$ - Stroke Band Pottery culture; $L P C$ - Lengyel-Polgár complex; TRB - Funnel Beaker culture;

$G A C$ - Globular Amphorae culture; $C W C$ - Corded Ware culture; $U$-Uneticé culture; $B B$ - Bell Beakers;

$B C$ - Baden culture; $Z C$ - Złota culture; $M C$ - Mierzanowice culture; $I C$ - Iwno culture; $D G$ - Dobre group; $R P C$ - Rzucewo/Pamariu culture; $L$ - pottery of the Linin type 
This view certainly stands in strong opposition to the hypothesis about Kuyavian origin of the TRB, common among majority of Polish, «Lowland» archaeologists [e.g. 29; 30; 25; 31].

One thing should be also added to this topic. Namely, from the perspective of above-mentioned hypothesis the term «proto-Neolithic», sometimes used with reference to the Mesolithic with pottery in the south-western Baltic zone [e.g. 10], seems to be justified, since the Neolithic Funnel Beaker culture was formed on this base.

The appearance of the «Funnel Beaker», Neolithic attributes (i.a. flexible agro-pastoral economy; relatively stable but at the same time adaptable settlement; «Funnel Beaker» pottery including the archetypical forms of funnel beaker, amphora, collared flask and plate; «new» funeral rite with its communal and monumental aspects) in other areas was the result of leapfrog colonisation and ecological infiltration [see 32]. However, not only these processes were responsible for the spread of the «Funnel Beaker» cultural model. As to the spread of the TRB patterns, it must be underlined that due to its attractiveness, they gained general acceptance within different cultural backgrounds - both in the late post-Linear, Neolithic and in the Late Mesolithic/proto-Neolithic, hunter-gatherer ones. We could figuratively say that the TRB was a kind of coat which wrapped various groups and different cultural traditions. Mesolithic and Neolithic traditions and echoes are in fact fairly well perceptible within TRB flint industries. Besides, few genetic records also indicate that the TRB is a specific blend of Early Neolithic and Mesolithic inputs, even considering the relatively late sites $[1 ; 2]$.

\section{The para-Neolithic communities}

At about mid- $4^{\text {th }}$ millennium BC the TRB cultural milieu ultimately dominated the region under our consideration. However, prehistory of the southern Baltic territories was more complicated in those days. Parallel to the second Neolithisation, independent, non-Neolithic ceramic phenomena grew in importance. As we already know, phenomena of this kind were already present in the $5^{\text {th }}$ millennium $\mathrm{BC}$ but they seem to be fairly selective. But in the $4^{\text {th }}$ millennium, particularly in the eastern part of the southern Baltic area, they became quite intensive. In archaeological terms they are represented mainly by the Neman culture (fig. 3: 4) and locally by the Zedmar culture (figs. 1, 2); sometimes it has been symbolically described in Polish literature as «Forest Pottery» and the whole phenomenon as «Forest Neolithic» [33]. This so-called Forest Neolithic, amazingly and surprisingly, is represented in vast areas, throughout of almost all Poland (fig. 1).

Significantly, agriculture practically played no role among Forest Neolithic until the end of their existence, possibly in the Early Bronze Age. Pottery constitutes in practice the only formal reference to the Neolithic. A certain duality characterizes this pottery. On the one hand, part of it is similar to the pottery of sub-Neolithic groups in Eastern Europe, but on the other hand, another part demonstrates mixing of features originating from the Forest Neolithic and from the local Neolithic cultures. This branch was discerned in the early 1970s by E. Kempisty [34; 35] as so-called Linin type. Although this type is most common in Masovia, in smaller quantities it also occurs in most regions within the eastern section of the southern Baltic area. Interestingly, four subtypes of the Linin pottery have been distinguished, due to the presence of Funnel Beaker, Globular Amphore, Corded Ware and Early Bronze elements there $[19 ; 33]$. This demonstrates that hunter-gatherer groups existed still in the late $3^{\text {rd }}$ millennium BC and that some contacts with Middle and Late Neolithic as well as Early Bronze groups were kept. This is also demonstrated by the TRB ceramic imports in some «Forest Neolithc» sites (Dudka - [21]), as well as by «Forest» ornaments and vessels in many TRB sites (fig. 3: 6,7), particularly in the Chełmno Land.

Archaeological data of yet another kind also indicate contacts between «expanding» TRB communities and «non-Neolithic» communities. We are referring here to the systematic presence of pottery with band-and-comb ornamentation and with temper of broken shells (fig. 3: 5) (the so-called Mątwy Cultural Component - [30; 36]) in almost all regional groups of the TRB in the Oder and Vistula basins. It is impossible to decisively settle here the dispute whether this pottery is of eastern origin (hunter-gatherers of the middle Dnieper and the lower Pripyat, with the agency of the Trypillia culture [30]), or maybe rather of north-eastern one (the Narva culture $[37 ; 27]$ ), or of rather local one [38]. Undoubtedly, it is the outcome of contacts and relationships between the TRB farmers and para-Neolithic hunters-gatherers. Perhaps, the fact of evident expansion of para-Neolithic cultures (mainly the Neman culture) in the southern Baltic area in the $4^{\text {th }}$ and $3^{\text {rd }}$ millennia BC (fig. 1), which has already been identified for a long time but somewhat overlooked by the specialists of the «proper» Neolithic, remains in a certain conjunction with this issue.

The fundamental problem (third one) is the genesis of all para-Neolithic phenomena. Researchers of the Forest Neolithic in Polish territories routinely seem to accept the idea of migration from the east and/or north-east as a fundamental explanation of its genesis [19; 33].

However, in our opinion, these «Forest Neolithic» groups could be of local origin; they would simply be an extension of the local development of the native Late Mesolithic. The patterns of ceramic production were only transmitted from the east and south-east («second», so-called southern tradition acc. to H. Piezonka [39, p. 566, fig. 13]). They were willingly adopted because of the cultural closeness to the east-European sub-Neolithic societies, in opposition to «foreign», central European Neolithic societies. These patterns were at the same time adapted and changed on the spot to some extent, among other things in effect of contacts with the said Neolithic groups.

What corroborates such a hypothesis? The already mentioned issue of flint inventories is of the utmost importance. At archaeological sites, «Forest» pottery routinely co-exists with lithics of the late Janisławice culture. In the research practice this has been considered to be a result of secondary mixing and consequently these pottery fragments and flints were separated. Very often they landed in separate sections of different regional or even archaeological museums. It turns out, however, that as a result of such approach, ceramic materials of the Neman culture in Poland are practically devoid of flint materials. In the light of current knowledge this is not possible, so the described practice has been wrong. Consequently, «Forest» pottery should be combined with local late-Janisławice flint artefacts, what is - by the way demonstrated by some latest research in north-eastern Poland, still unpublished (e.g. at Grądy Woniecko). 

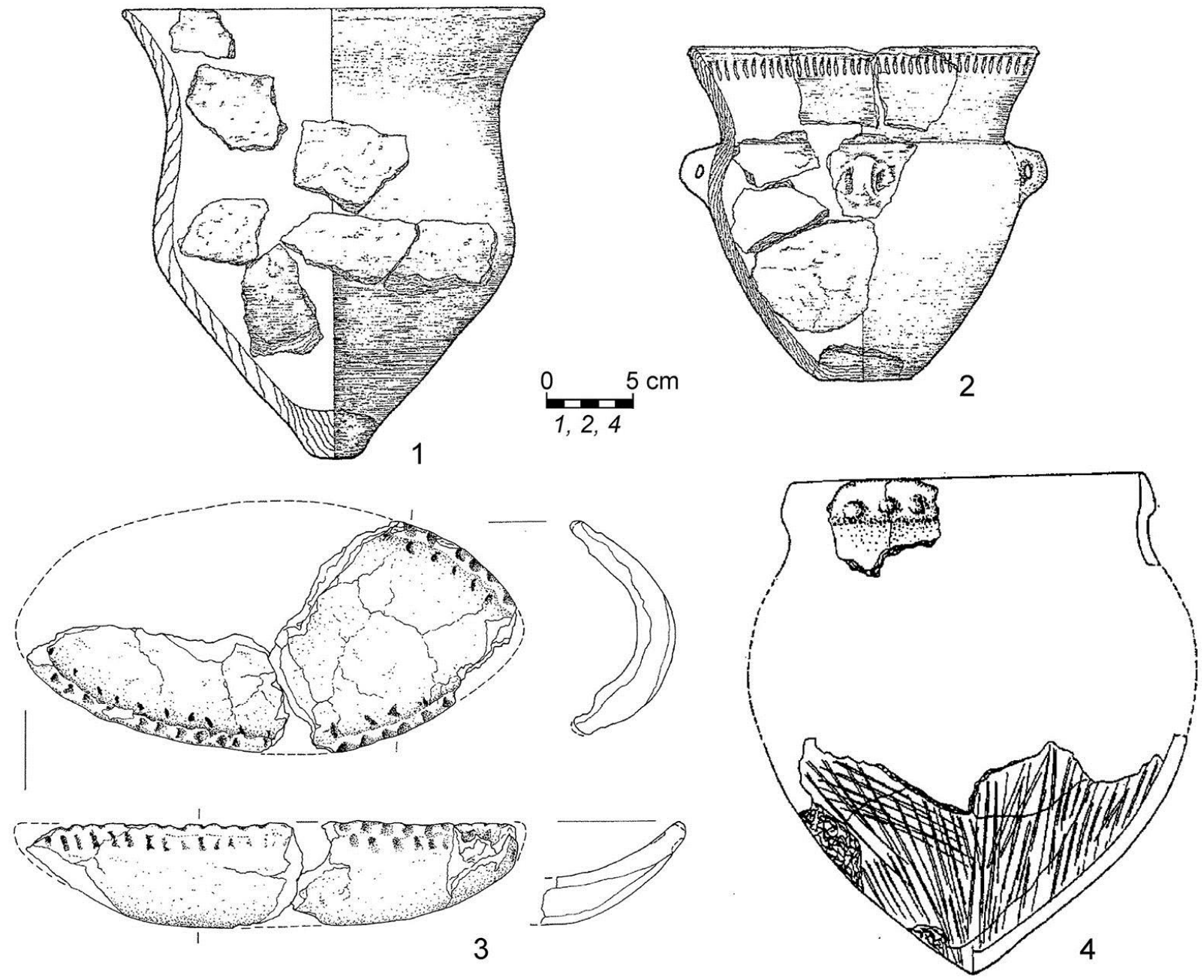

3
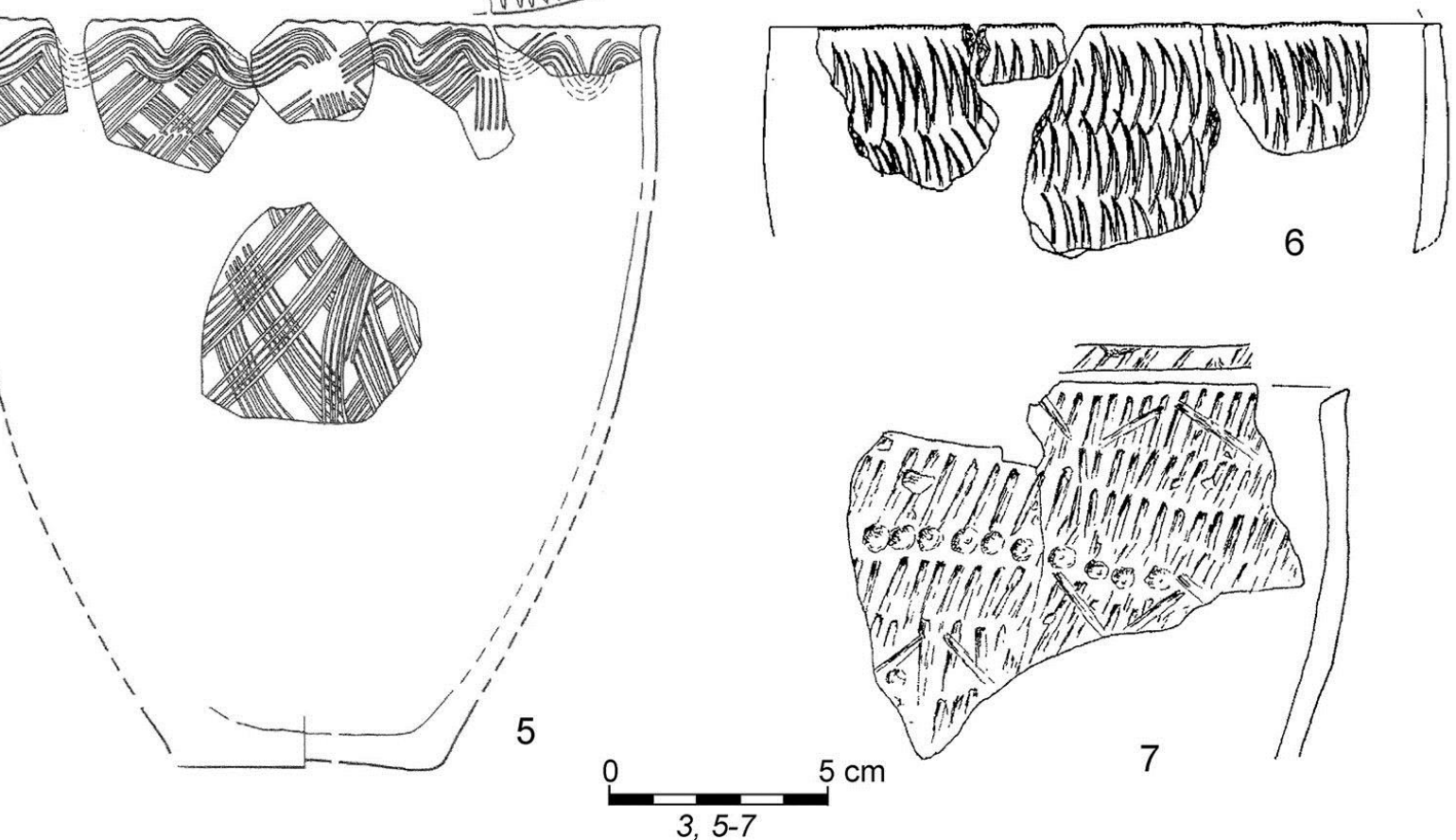

Figure 3 - Selected pottery of the early Funnel Beaker culture (TRB), proto-Neolithic and para-Neolithic;

1, 2- Pottery of the Ertebølle culture (1) and the early TRB (2) from the site in Tanowo 3 [10, plates LXIII, LXIV];

3 - pottery referred to as a transitional between the Mesolithic pottery (Ertebølle?) and the TRB pottery (lamp characteristic of the Ertebølle culture with an early TRB ornament) from the site in Dąbki 9 [28]; 4- pottery of the Neman culture from the site in Sośnia (NE Poland) [33]; 5 - pottery with the band-and-comb ornamentation form the site in Tarkowo 23 [38];

6 - TRB pottery with Neman influences from the site in Brukniewo (eastern Pomerania) [19, plate 29]; 7- TRB pottery with para-Neolithic elements from the site in Klamry 8 (Chełmno Land) [27, plate 8] 
In such a situation, a strict separation of the Late Mesolithic and «Forest Neolithic» loses its original sense, the two being two branches of the same phenomenon, that is to say of the hunting-gathering populations operating in the Middle Holocene forests of east-central Europe. The phenomenon under discussion existed from the late $5^{\text {th }}$ millennium BC until the Early Bronze Age, simultaneously with Neolithic units. This phenomenon was made up of communities whose members were well aware that it is possible to cultivate land and to raise animals, but they quite consciously did not make use of that possibility. Therefore this cultural model, formed here, in the conditions of the east-central Europe in the $4^{\text {th }}$ and $3^{\text {rd }}$ millennia BC may be called «para-Neolithic» or perhaps even «alternative Neolithic».

\section{Conclusions}

The following points should be highlighted as general conclusions (fig. 2):

- During the whole Neolithic, and probably also in the Early Bronze Age, in the southern Baltic territory we are dealing with the coexistence of groups of Neolithic farmers and Late Mesolithic / proto-Neolithic / paraNeolithic hunter-gatherers.

- The Funnel Beaker culture is an autochthonous phenomenon associated with the transmission and acceptance of new cultural patterns by both Mesolithic / proto-Neolithic hunter-gatherers and the late, post-Linear farmers. The initial forms of these patterns were formed in the south-western Baltic zone, on the basis of local proto-Neolithic communities.

- However, only some of the Late Mesolithic huntergatherers accepted Funnel Beaker patterns. The remainder (ca. $40 / 50 \%$ - this estimation is perhaps SF, but is based on numerical relation of «Forest Neolithic» sites to the Late Mesolithic and earlier TRB ones) successfully carried on the traditional lifestyle, supplementing it with some Neolithic or rather Neolithic-like elements. This para-Neolithic cultural model in more northern part of the area under consideration, particularly in Masovia and north-eastern Poland, laid the foundations for the substantial share of the Early Bronze cultural development.

\section{REFERENCES:}

1. Bramanti B., Thomas M.G., Haak W., Unterlaender M., Jores P., Tambets K., Antanaitis-Jacobs I., Haidle M.N., Jankauskas R., Kind C.-J., Lueth F., Terberger T., Hiller J., Matsumura S., Forster P., Burger J. Genetic discontinuity between local hunter-gatherers and Central Europe's first farmers // Science. 2009. Vol. 326, № 5949. P. 137-140.

2. Brandt G., Haak W., Adler Ch.J., Roth Ch., Szécsényi-Nagy A., Karimnia S., Möller-Rieker S., Meller H., Ganslmeier R., Friederich S., Dresely V., Nicklisch N., Pickrell J.K., Sirocko F., Reich D., Cooper A., Alt K.W. The Genographic Consortium. Ancient DNA reveals key stages in the formation of Central European mitochondrial genetic diversity // Science. 2013. Vol. 342, № 6155. P. 257-261.

3. Brandt G., Szécsényi-Nagy A., Roth Ch., Alt K.W., Haak W. Human paleogenetics of Europe - The known knowns and the known unknowns // Journal of Human Evolution. 2015. Vol. 79. P. 73-92.

4. Haak W., Balanovsky O., Sanchez J.J., Koshel S., Zaporozhchenko V., et al. Ancient DNA from European Early Neolithic Farmers Reveals Their Near Eastern Af- finities // PLoS One, Biology. 2010. Vol. 8, № 11: e1000536. doi:10.1371/journal.pbio.1000536.

5. Rybicka M., Rzepecki S. Przyczynek do badań nad kulturą późnej ceramiki wstęgowej w Polsce północnowschodniej // Łódzkie Sprawozdania Archeologiczne. 2001. Vol. 7. P. 7-13.

6. Rybicka M., Wysocki J. Materiały kultury późnej ceramiki wstęgowej z Równiny Dolnej, st. III, gm. Korsze, woj. warmińsko-mazurskie (wyniki badań w 2001 roku) // Prace i Materiały Muzeum Archeologicznego i Etnograficznego w Łodzi, Seria Archeologiczna. 2004. Vol. 42 (2002-2003). P. 79-107.

7. Bigos M. Północna granica zasięgu osadnictwa kultury późnej ceramiki wstęgowej // Folia Praehistorica Posnaniensia. 2014. Vol. 19. P. 7-40.

8. Grygiel R. Neolit i początki epoki brązu w rejonie Brześcia Kujawskiego i Osłonek, tom II: Środkowy neolit. Grupa brzesko-kujawska kultury lendzielskiej. Łódź: Fundacja im. K. Jażdżewskiego, Muzeum Archeologiczne i Etnograficzne w Łodzi, 2008. 2062 p.

9. Kotula A., Czekaj-Zastawny A., Kabaciński J., Terberger T. Find distribution, taphonomy and chronology of the Dąbki site // The Dąbki Site in Pomerania and the Neolithisation of the North European Lowlands (C. 5000-3000 calBC) / eds. J. Kabaciński, S. Hartz, D.C.M. Raemaekers, T. Terberger. Rahden / Westf.: Marie Leidorf, 2015. P. 113-136.

10. Galiński T. Protoneolit. Obozowiska łowieckie ze schyłku okresu atlantyckiego w Tanowie na Pomorzu Zachodnim. Warszawa: Instytut Archeologii i Etnologii Polskiej Akademii Nauk, 2016. 256 p.

11. Schild R. Datowanie radiowęglowe otwartych stanowisk piaskowych późnego paleolitu i mezolitu. Czy mezolit w Europie trwał do drugiej wojny światowej // Zeszyty Naukowe Politechniki Śląskiej, MatematykaFizyka. 1990. Vol. 61. P. 153-163.

12. Schild R. The perils of dating open-air sandy sites of the North European Plain // Harvesting the Sea, Farming the Forest: The Emergence of Neolithic Societies in the Baltic Region / eds. M. Zvelebil, L. Domańska, R. Dennell. Sheffield: Sheffield Academic Press, 1998. P. 71-76.

13. Nowak M. Drugi etap neolityzacji ziem polskich. Kraków: Instytut Archeologii Uniwersytetu Jagiellońskiego, 2009. 717 p.

14. Kabaciński J. Chwalim stanowisko 1 // Region Wojnowo. Arkadia łowców i zbieraczy / ed. M. Kobusiewicz. Poznań: Instytut Archeologii i Etnologii Polskiej Akademii Nauk, 2016. P. 395-438.

15. Kobusiewicz M., Kabaciński J. Chwalim. Subboreal Hunter-Gatherers of the Polish Plain. Poznań: Instytut Archeologii i Etnologii Polskiej Akademii Nauk, 1993. $130 \mathrm{p}$.

16. Kozłowski J.K., Kozłowski S.K. Epoka kamienia na ziemiach polskich. Warszawa: Państwowe Wydawnictwo Naukowe, 1977. 401 p.

17. Kotula A. Contact and adaptation - The early local pottery at Dąbki and its relations to neigbouring hunter-gatherer ceramics // The Dąbki Site in Pomerania and the Neolithisation of the North European Lowlands (C. 5000-3000 calBC) / eds. J. Kabaciński, S. Hartz, D.C.M. Raemaekers, T. Terberger. Rahden/Westf.: Marie Leidorf, 2015. P. 175-202.

18. Kozicka M. Absolute chronology of the Zedmar culture: re-thinking radiocarbon dates // Geochronometria. 2017. in press. 
19. Józwiak B. Społeczności subneolitu wschodnioeuropejskiego na Niżu Polskim w międzyrzeczu Odry i Wisły. Poznań: Uniwersytet Adama Mickiewicza, 2003. $283 \mathrm{p}$.

20. Czekaj-Zastawny A. Imported Danubian pottery in the Late Mesolithic context in Dąbki, The Dąbki Site in Pomerania and the Neolithisation of the North European Lowlands (C. 5000-3000 calBC) / eds. J. Kabaciński, S. Hartz, D.C.M. Raemaekers, T. Terberger. Rahden/Westf.: Marie Leidorf, 2015. P. 219-232.

21. Gumiński W. Importy i naśladownictwa ceramiki kultury brzesko-kujawskiej i kultury pucharów lejkowatych na paraneolitycznym stanowisku kultury Zedmar Szczepanki na Mazurach // Na rubieży kultury. Badania nad okresem neolitu i wczesną epoką brązu / eds. U. Stankiewicz, A. Wawrusiewicz. Białystok: Muzeum Podlaskie w Białymstoku, 2011. P. 149-160.

22. Nowak M. Ubiquitous settlers, consequent farmers, and monument builders // The Past Societies. The Polish Lands From the First Evidence of Human Presence to the Early Middle Ages. Vol. 2: 5500-2000 BC / ed. P. Włodarczak. Warszawa: Institute of Archaeology and Ethnology of the Polish Academy of Sciences, 2017. P. 125-170.

23. Wierzbicki J. Wielka kolonizacja. Społeczności kultury pucharów lejkowatych w dorzeczu środkowej Warty. Poznań: Stowarzyszenie Naukowe Archeologów Polskich, Oddział w Poznaniu, 2013. 373 p.

24. Kruk J., Alexandrowicz S.W., Milisauskas S., Śnieszko Z. Osadnictwo i zmiany środowiska naturalnego wyżyn lessowych. Studium archeologiczne i paleogeograficzne nad neolitem w dorzeczu Nidzicy. Kraków: Instytut Archeologii i Etnologii Polskiej Akademii, 1996. $139 \mathrm{p}$.

25. Kukawka S. Początki kultury pucharów lejkowatych na Niżu Polskim // Folia Praehistorica Posnaniensia. 2015. Vol. 20. P. 277-300.

26. Kotula A., Piezhonka H., Terberger T. New pottery dates on the Mesolithic-Neolithic transition in the northcentral European lowlands // The Dąbki Site in Pomerania and the Neolithisation of the North European Lowlands (C. 5000-3000 calBC) / eds. J. Kabaciński, S. Hartz, D.C.M. Raemaekers, T. Terberger. Rahden/ Westf.: Marie Leidorf, 2015. P. 489-509.

27. Kukawka S. Subneolit północno-wschodnioeuropejski na Niżu Polskim. Toruń: Uniwersytet Mikołaja Kopernika 2010. 268 p.

28. Czekaj-Zastawny A., Kabaciński J. The early Funnel Beaker culture at Dąbki // The Dąbki Site in Pomerania and the Neolithisation of the North European Lowlands (C. 5000-3000 calBC) / eds. J. Kabaciński,
S. Hartz, D.C.M. Raemaekers, T. Terberger. Rahden/ Westf.: Marie Leidorf, 2015. P. 203-217.

29. Domańska L. Geneza krzemieniarstwa kultury pucharów lejkowatych na Kujawach. Łódź: Uniwersytet Łódzki, 1995.

30. Kośko A. Udział południowo-wschodnio-europejskich wzorców kulturowych w rozwoju niżowych społeczeństw kultury pucharów lejkowatych. Poznań: Uniwersytet Adama Mickiewicza, 1981. 222 p.

31. Rzepecki S. The Roots of Megalithism in the TRB Culture. Łódź: Instytut Archeologii Uniwersytetu Łódzkiego \& Fundacja Uniwersytetu Łódzkiego, 2011. $251 \mathrm{p}$.

32. Zvelebil M. The agricultural transition and the origins of Neolithic society in Europe // Documenta Praehistorica. 2001. Vol. 28. P. 1-27.

33. Kempisty E. Neolityczne kultury strefy leśnej w północnej Polsce // Problemy epoki kamienia na Pomorzu / ed. T. Malinowski. Słupsk: Wyższa Szkoła Pedagogiczna w Słupsku, 1983. P. 175-199.

34. Kempisty E. Materiały tzw. kultury ceramiki grzebykowo-dołkowej z terenu Mazowsza i Podlasia // Wiadomości Archeologiczne. 1972. Vol. 37. P. 411-483.

35. Kempisty E. Kultura ceramiki grzebykowo-dołkowej na Mazowszu i Podlasiu // Wiadomości Archeologiczne. 1973. Vol. 38. P. 3-76.

36. Kośko A. Osady kultury pucharów lejkowatych w Inowrocławiu-Matwach woj. Bydgoszcz, stanowisko 1. Inowrocław: Uniwersytet Adama Mickiewicza, 1988. $163 \mathrm{p}$.

37. Kukawka S. Udział komponentu północnowschodniego w wytwórczości ceramicznej kultury pucharów lejkowatych na Ziemi Chełmińskiej (na marginesie pracy A. Kośko Osady kultury pucharów lejkowatych w Inowrocławiu-Mątwach, woj. Bydgoszcz, st. 1. Inowrocław 1988) // Archeologia Polski. 1990. Vol. 35. P. 139-160.

38. Prinke D. Społeczności neolitu na peryferiach kujawskiego mezoregionu kulturowego // Na pograniczu światów. Studia z pradziejów międzymorza bałtyckopontyjskiego ofiarowane Profesorowi Aleksandrowi Kośko w 60. rocznicę urodzin. eds. J. Bednarczyk, J. Czebreszuk, P. Makarowicz, M. Szmyt. Poznań: Wydawnictwo Poznańskie, 2008. P. 423-450.

39. Piezonka H. Jäger, Fischer, Töpfer. Wildbeutergruppen mit früher Keramik in Nordosteuropa im 6. und 5. Jahrtausend v. Chr. Bonn: Deutsches Archäologisches Institut \& Rudolf Habelt, 2015. 437 p.

40. Nowak M. Middle and Late Holocene huntergatherers in East Central Europe: changing paradigms of the «non-Neolithic» way of life // Documenta Praehistorica. 2007. Vol. 34. P. 89-103.

\section{ВТОРОЙ ЭТАП НЕОЛИТИЗАЦИИ И ПАРА-НЕОЛИТ В ЮЖНОЙ ЧАСТИ БАЛТИЙСКОГО МОРЯ} (C) 2017

\footnotetext{
Новак Марек, доктор наук, доцент института археологии Ягеллонский университет (г. Краков, Республика Польша)
}

\footnotetext{
Аннотация. Возникновение неолита, как экономической системы, основанной на земледелии, в восточноцентральной Европе ассоциируется с появлением обществ отражающихся в культуре линейно-ленточной керамики около 5500 до н.э. Эти общества заселяли только небольшие анклавы, отличающиеся удобными для земледелия условиями. Ситуация такого типа сохранялась в 5 тысячелетии до н.э., когда обсуждаемая территория была заселена пост-Линейными группами. Следовательно, в то время охотники-собиратели занимали около 70\% этих территорий. Такая ситуация изменилась с 4200/4100 до н.э. и далее, благодаря формированию и впечатляющей территориальной «экспансии» культуры воронковидных кубков (КВК). Эта экспансия охватывала как территории ранее населенные охотниками-собирателями, так и земледельцами. Около 3500 до н.э. неолитические группы занимали практически все территории, указанные выше. Одновременно с пер-
} 
вой и второй неолитизациями, происходили отдельные процессы «керамизации» в период позднего мезолита. Если в 5 тысячелетии до н.э. они были достаточно избирательными, в 4 тысячелетии интенсивность данного процесса значительно возросла. Здесь сформировалась новая культурная модель, которую можно было бы назвать «пара-неолитом». Археологические данные указывают на контакты между КВК и паранеолитическими обществами. При этом в последних (прежде всего в неманской культуре) также наблюдается существенное территориальное развитие.

Ключевые слова: Южная Прибалтика; неолит; пара-неолит; культура воронковидных кубков; неолитизация; керамизация; культура линейно-ленточной керамики; земледелие; хронология; охотники и рыболовы; мезолит; культура эртебелле; лесной неолит.

УДК 902/904

Статья поступила в редакцию 19.10.2017

\title{
ДЕТСКИЕ И ПОДРОСТКОВЫЕ ПОГРЕБЕНИЯ НАЧАЛА МЕДНО-БРОНЗОВОГО ВЕКА НА ПРИМЕРЕ МАЙКОПСКО-НОВОСВОБОДНЕНСКОЙ ОБЩНОСТИ
}

(C) 2017

\author{
Кореневский Сергей Николаевич, доктор исторических наук, \\ ведущий научный сотрудник отдела бронзового века \\ Институт археологии РАН (г. Москва, Российская Федераџия)
}

\begin{abstract}
Аннотация. В статье рассматривается проблема детских и подростковых захоронений майкопсконовосвободненской общности (МНО) Предкавказья. Установлено, что в вариантах МНО, в которых под большими насыпями курганов хорошо представлены захоронения лидеров с оружием, инструментами и золотом, погребения детей крайне редки и специфичны. В немногих зафиксированных захоронениях детей из очерченного круга памятников в состав инвентаря входит оружие, золото, инструменты. Таков контекст галюгаевско-серегинского, долинского вариантов и новосвободненской группы горизонта гробниц. Подобная ситуация позволяет предполагать передачу ребенку по наследству высокого статуса его родителей и специфические культы детского захоронения.

В погребениях псекупского варианта погребения с символикой оружия и инструментов немногочисленны, а большие курганы не известны. Много захоронений вообее не содержат оружия и инструментов. Детские захоронения с керамикой псекупского варианта или близкой ему ранней новосвободненской группы зафиксированы как грунтовое детское кладбище. Они также включаются в подкурганные комплексы захоронений вместе с погребениями взрослых людей. Детские захоронения псекупского варианта и ранней новосвободненской группы не содержат оружия, инструментов, а также украшений из меди и золота.
\end{abstract}

Дважды открыты погребения детей племен МНО в сосудах.

Таким образом, люди майкопско-новосвободненской общности относились к детским погребениям неодинаково. Нередко на традиции погребения ребенка или подростка, символику сопровождающего его инвентаря могли влиять тенденции к элитарному ранжированию захоронений с военно-производственной символикой и специфика самих культов детских погребений для каждого из вариантов МНО.

Ключевые слова: погребальный обряд; дети; катакомба; кромлех; курган; насыпь; элита; золото; серебро; ранжирование; украшения; подвески; престиж; погребение; традиция; культ; керамика; оружие; тесло; орудия труда; сосуд; охра; статус; костюм; культура; признак; труд; лидер; вариант; типология.

Возраст детства и отрочества до момента инициации в первобытных, догосударственных обществах всегда рассматривался как особое состояние подрастающего человека. Детская смертность была высока, и у носителей разных культур сложились неоднозначные способы захоронения детей и подростков. Ситуации с обрядом детских погребений, по данным археологии, были различными. Так, например, на поселении Тель эс Савван хассунской культуры встречены захоронения детей в площади поселения под полами жилищ с богатыми наборами украшений, статуэтками богинь и керамикой [1] (конец VI - начало V тыс. до н.э.). Н.Я. Мерперт и Р.М. Мунчаев предполагали существование даже специальных детских ритуалов погребения у населения древней Месопотамии этого времени [2].

Детские погребения с украшениями костюма открыты в большом количестве в крупном могильнике Дуранкуклак в Болгарии, где представлены комплексы культуры Хаманджия и Варна V тыс. до н.э. [3; 4]. Как правило, оружия и орудий ударного действия в этих захоронениях не наблюдается.
Несколько иная картина прослежена в Хвалынском могильнике в Среднем Поволжье конца VI начала V тыс. до н.э. [5]. Здесь в детских могилах попадаются не только украшения, но и орудия труда.

Общее отражение общественного устройства культур, оставивших упомянутые выше детские некрополи, одинаково показывает отсутствие погребений лидеров или воинов, для которых бы сородичи тратили большие усилия на возведение над их захоронениями монументальных сооружений или выделения их специально индивидуальными комплексами вне родовых кладбищ. Даже элитные погребения с обилием золота могильника Варна (например, п. 43) не имели внешних признаков, на создание которых был бы затрачен большой труд соплеменников.

В данной статье мы рассмотрим имеющуюся информацию о погребениях детей и подростков совершенно иной культурной среды племен майкопсконовосвободненской общности IV тыс. до н.э. Предкавказья. Ее население, как известно, концентрировало огромные усилия для возведения курганных насыпей над могилами своей элиты. Оно обладало 